\title{
Problematyka oświatowa na łamach czasopism społeczno-ekonomicznych Królestwa Polskiego połowy XIX w.
}

Dyskurs toczony obecnie przez historyków, po co i jak pisać historię w początkach trzeciego tysiąclecia ${ }^{1}$, skłania również do poszukiwania nowych źródeł dla „starych” tematów bądź innego spojrzenia na źródła dotychczas wykorzystywane. Dla badań nad szeroko definiowaną historią społeczną z pewnością istotnym źródłem staje się prasa. Oddziałując na poglądy czytelników, sama musiała jednocześnie podlegać wpływowi obiegowych sądów i wyobrażeń, stąd jest ważnym świadectwem polskiego życia społecznego, politycznego, gospodarczego, naukowego, kulturalnego i w naukach humanistycznych winna stanowić istotny rodzaj dokumentu źródłowego. Niestety, daleko jeszcze do stworzenia pełnej retrospektywnej bibliografii czasopism, gromadzącej nie tak same tytuły, jak charakteryzującej ich zawartość i przydatność do badań. Poniższy tekst jest próbą odpowiedzi na pytanie, czy czasopisma społeczno-ekonomiczne, które w liczbie kilku tytułów ukazywały się w Królestwie Polskim (faktycznie w Warszawie) w okresie międzypowstaniowym, mogą stać się źródłem dla badań nad dziejami szkolnictwa i oświaty.

Zanim przejdę do poszukiwania odpowiedzi na tak postawione pytanie, przynajmniej w zarysie naszkicuję niektóre aspekty ówczesnych uwarunkowań określających możliwości działania mieszkańców Królestwa Polskiego, warunków rozwoju szkolnictwa i ukazywania się prasy.

Klęska w wojnie z Rosją w 1831 r., a przede wszystkim represje, jakie spadły na Królestwo Polskie w epoce paskiewiczowskiej spowodowały, że przed Polakami, dla których odrażający był serwilizm, zamknęły się możliwości aktywności politycznej na terenie kraju. Stąd też ci z nich, którzy nie wyjechali na emigrację,

* Dr hab., prof. UŁ, Katedra Historii Polski XIX w., Instytut Historii, Wydział FilozoficznoHistoryczny Uniwersytet Łódzki, 90-219 Łódź, ul. Kamińskiego 27a.

1 Zob. m.in.: E. D o m a ń s k a, Mikrohistorie. Spotkania w międzyświatach, wyd. Il poprawione, Poznań 2005. 
a jednocześnie - kierując się obowiązkiem obywatelskim - podejmowali działalność dla dobra publicznego, zostali zmuszeni do poszukiwania innych płaszczyzn aktywności.

Spostrzeżenie to dotyczy zwłaszcza ówczesnej elity społecznej, którą w Królestwie Polskim tworzyli ziemianie i nieliczna jeszcze inteligencja, najczęściej pochodzenia szlacheckiego. Inteligenci, po powstaniu listopadowym element szczególnie podejrzany, nie mieli niemal dostępu do elity władzy, którą w państwie zaborczym tworzyły dwór monarszy, korpusy urzędnicze i oficerskie, a jej bazę rekrutacyjną stanowili przede wszystkim dworianie rosyjscy oraz ulegli wobec władzy Polacy i Litwini. Najbardziej energiczni przedstawiciele polskiej elity, chcąc nadal służyć ojczyźnie (tej podzielonej przez zaborców) i społeczeństwu, w myśl wyznawanej od wieków zasady noblesse oblige, zaangażowali się w legalne prace, odrzucając tym samym poczynania insurekcyjne i działania konspiracyjne ${ }^{2}$. Istotnym celem tej grupy stały się przede wszystkim dążenia do modernizacji gospodarki ziemiańskiej i organizmu społecznego, w takim kierunku, aby nadal zachować dominującą pozycję w ówczesnej strukturze społecznej. Podjęli oni aktywność gospodarczą, społeczną i kulturalną za pomocą środków niepolitycznych ${ }^{3}$. Choć kierowali się nieraz interesem osobistym i korzyściami własnej grupy społecznej, obiektywnie należy stwierdzić, że ich działalność miała aspekt ogólniejszy. Przyczyniała się nie tylko do trwania, lecz także rozwoju narodu pozbawionego własnego państwa. Przywołując opinię Andrzeja Chwalby, ci liberalni i oświeceni przedstawiciele polskiej elity uważali się za jedyną warstwę, „która była w stanie przeprowadzić «własny» lud przez groźne europejskie «morze czerwone»"4.

Po klęsce powstania listopadowego carskie represje szczególnie odcisnęły swoje piętno na szkolnictwie wszystkich szczebli, a sytuacja z każdym rokiem stawała się coraz bardziej opłakana. Namiestnik Królestwa Polskiego, książę warszawski Iwan Paskiewicz, podzielając zdanie cara Mikołaja I o niebezpieczeństwie płynącym dla systemu samodzierżawia i panowania rosyjskiego nad Polakami z książek i szkół, podejmował decyzje poważnie szkodzące polskiej oświacie i systemowi szkolnictwa ${ }^{5}$. Zlikwidowano Uniwersytet Warszawski i zakazano funkcjonowania mającego wielkie zasługi Towarzystwa Przyjaciół Nauk.

${ }^{2}$ Por. W. C a b a n, Ziemiaństwo Królestwa Polskiego wobec ruchu niepodległościowego w latach 1833-1856, [w:] Ziemiaństwo a ruchy niepodległościowe w Polsce XIX-XX wieku, red. W. C a ban, M. B. Markowski, Kielce 1994, s. 14-15; W. A. D jakow, A. Gałkowski, W. Śli w o w ska, W. M. Z a j c e w, Uczestnicy ruchów wolnościowych w latach 1832-1855 (Królestwo Polskie). Przewodnik biograficzny, Wrocław 1990 (trudno wśród zamieszczonych nazwisk odnaleźć przedstawicieli zamożnego ziemiaństwa i arystokracji).

3 Typowym przykładem takiej postawy był jeden z liderów ówczesnej elity Królestwa Polskiego Tomasz Potocki. Zob. J. K i t a, Tomasz Potocki (1809-1861). Ewolucja postaw ziemianina polskiego, Łódź 2007.

${ }^{4}$ A. C h w a l b a, Historia Polski 1795-1918, Kraków 2000, s. 287.

5 Szerzej zob.: M. S z c z e r b a t o w, Rządy księcia Paskiewicza w Królestwie Polskim (18321847), Warszawa 1900; J. K u c harze w s k i, Epoka paskiewiczowska... Losy oświaty, Warszawa-Kraków 1914; K. P o z n a ń s k i, Oświata i szkolnictwo w Królestwie Polskim 1831-1869. Lata zmagań i nadziei, t. 1: Przebudowa systemu szkolnego i wychowania w Królestwie Polskim w latach 1831-1839, Warszawa 2001. 
Trwale pozbawiono Polaków instytucji, które mogłyby zapewnić rozwój kultury i nauki. Niedostateczna była sieć szkół średnich, gimnazjów, a już zupełnie katastrofalna sytuacja miała miejsce na poziomie szkół elementarnych. Jak obliczał znakomity polski historyk, Stefan Kieniewicz, analfabetyzm na wsi przekraczał $90 \%$, a sytuacja w miastach w tym względzie nie była dużo lepsza ${ }^{6}$. Co prawda językiem wykładowym pozostawał polski, ale wśród nauczycieli szkół rządowych nie brakowało serwilistów i karierowiczów, widzących w realizacji carskiej polityki możliwość awansów.

Polityka represji, realizowana przez I. Paskiewicza, ograniczała możliwość rozwoju czasopiśmiennictwa w Królestwie Polskim, ale na szczęście nie zahamowała jej. W latach czterdziestych i pięćdziesiątych XIX w. ukazywało się niewiele polskich gazet i czasopism, a uzyskanie koncesji na nowy tytuł graniczyło wręcz z cudem ${ }^{7}$. Ponadto funkcjonowanie prasy w Królestwie Polskim było determinowane przez ostrą i drobiazgową cenzurę, utrudniającą pojawienie się jakiejkol-

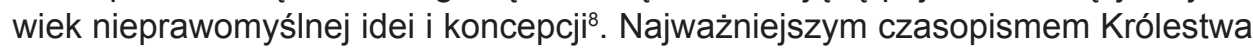
Polskiego w tym okresie był z pewnością miesięcznik „Biblioteka Warszawska”, założony w 1841 r., adresowany do ogółu środowisk intelektualnych. Stał się on czymś więcej niż tylko czasopismem, odgrywał rolę ośrodka naukowo-kulturalnego, grupującego większość najwybitniejszych indywidualności naukowych i pisarskich tej części ziem polskich. Czasopismo było przez cały czas subsydiowane przez Spółkę Nakładową, którą tworzyli zamożni przedstawiciele ziemiaństwa i warszawskiej burżuazji9. Propagowało rozwój nauki, w której widziano środek przebudowy społecznej i modernizacji gospodarki kraju. Publicyści miesięcznika za konieczne uważali ewolucyjne zmiany w zacofanej strukturze społeczno-gospodarczej i w tym też celu na łamach pisma optowali za rozwojem przemysłu i handlu, za unowocześnieniem gospodarki rolnej, propagowali oczynszowanie chłopów i wzmocnienie pozycji mieszczaństwa w strukturze społecznej Królestwa Polskiego. Teksty poświęcone rozwojowi pozaszkolnej oświaty zawodowej niejednokrotnie pojawiały się na szpaltach „Biblioteki Warszawskiej”.

Jednak na drodze realizacji procesów modernizacyjnych, podjętych przez przedstawicieli polskiej elity, obok „Biblioteki Warszawskiej”, najistotniejsze znaczenie miały czasopisma społeczno-ekonomiczne, pośród których na plan pierwszy zdecydowanie wysuwały się „Roczniki Gospodarstwa Krajowego”. Czasopismo to, począwszy od pierwszej chwili ukazywania się, czyli od 24 czerwca 1842 r. ${ }^{10}$,

${ }^{6}$ W 1860 r. w skali Królestwa Polskiego było niemal 80\% analfabetów. Chłop czy robotnik potrafiący się podpisać należeli do rzadkich wyjątków. S. K i e n i e w i c z, Historia Polski 1795-1918, Warszawa 1983, s. 211.

7 Na terenie Królestwa Polskiego pomiędzy 1832 a 1861 r. ukazywało się do 30 tytułów prasowych rocznie. Większość z nich trwała tylko przez kilka lat, a znaczna część to efemerydy. Tylko 7 tytułów przetrwało cały wspomniany okres. Zob. E. To m a s z e w s k i, Prasa Królestwa Polskiego i ziem litewsko-ruskich okresu międzypowstaniowego (1831-1864), [w:] Historia prasy polskiej, red. J. 七 o j e k, t. 1: Prasa polska w latach 1661-1864, Warszawa 1976, tab. 2, s. 111-113.

8 Tamże, s. 119.

9 J. K i t a, Tomasz Potocki..., s. 315-317.

10 Wydawanie czasopisma zapoczątkowano specjalnie w tym dniu, czyli w dniu św. Jana (początek roku gospodarskiego). 
stało się de facto głównym organem tzw. „partii ziemiańskiej”, propagującej reformy gospodarcze i związane z nimi propozycje przemian społecznych. Wśród założycieli pisma były osoby najbardziej wówczas wpływowe i dobrze znane nie tylko w skali kraju, ale i poza granicami Królestwa Polskiego, m.in. Andrzej Zamoyski, Tomasz Potocki, Aleksander Ostrowski, Stanisław Aleksandrowicz, Ludwik Górski ${ }^{11}$. „Roczniki Gospodarstwa Krajowego” od 1858 r. stały się organem prasowym najważniejszej legalnej organizacji funkcjonującej wówczas na ziemiach polskich, czyli Towarzystwa Rolniczego, którego aktywność daleko wykraczała poza ramy nakreślone w statucie ${ }^{12}$. W latach 1842-1864 wydano łącznie 42 tomy pisma. Początkowo wychodziło ono jako kwartalnik i było redagowane przez Kajetana Garbińskiego, po 1847 r. - przez Andrzeja Zamoyskiego, Seweryna Zdzitowieckiego i Władysława Garbińskiego. „Roczniki Gospodarstwa Krajowego” od początku swojego istnienia cieszyły się znacznym powodzeniem i tylko w niektórych okresach popularność pisma, a tym samym liczba prenumeratorów, nieco zmniejszała się. Pismu jednak nie groził wówczas upadek, gdyż było ciągle subsydiowane przez grono najzamożniejszych ziemian Królestwa Polskiego.

Inne tytuły ówczesnych czasopism społeczno-ekonomicznych, mających debit na terenie Królestwa Polskiego to: „Tygodnik Rolniczo-Technologiczny”, „Korespondent Handlowy, Przemysłowy i Rolniczy”, „Gazeta Handlowa, Przemysłowa i Rolnicza” oraz „Przegląd Rolniczy, Handlowy i Przemysłowy”. Niektóre z tych pism ukazywały się początkowo jako dodatki do gazet codziennych, następnie przekształciły się w samodzielne czasopisma. Periodyki te szczególnie wiele uwagi poświęcały propagowaniu modernizacji techniki rolnej i gospodarki wiejskiej. Z biegiem lat na ich łamach pojawiły się również artykuły poświęcone problematyce przemysłowej i handlowej ${ }^{13}$.

„Tygodnik Rolniczo-Technologiczny” wychodził w Warszawie od 1835 do 1850 r. Pismo ukazujące się raz na tydzień w objętości jednego arkusza założył i przez cały czas redagował Jan Nepomucen Kurowski, znany ówczesny agronom, pisarz i popularyzator wiedzy rolniczej. Był autorem szeregu podręczników i poradników oraz przekładów z języków obcych na tematy rolnicze ${ }^{14}$. „Tygodnik Rolniczo-Technologiczny" stanowił pierwsze pismo społeczno-ekonomiczne, ukazujące się w Królestwie Polskim po klęsce powstania listopadowego ${ }^{15}$. Zawierał

11 W tomie 30. z 1857 r. „Roczników Gospodarstwa Krajowego” (dalej: RGK), s. 163-164 znajduje się Lista członków redakcji współwłaścicieli „Roczników Gospodarstwa Krajowego” wraz z drzeworytem ich przedstawiającym. Ogólną charakterystykę czasopisma zob.: M. W i g l u s z o w a, „Roczniki Gospodarstwa Krajowego” (1842-1864) - pierwsza większa zbiorowa inicjatywa wydawnicza rolników polskich, „Studia i Materiały z Dziejów Nauki Polskiej” 1972, z. 23.

12 Na temat Towarzystwa Rolniczego zob. szerzej: W. G r a b s k i, Historia Towarzystwa Rolniczego 1858-1861, t. 1-2, Warszawa 1904; wiele istotnych informacji odnajdujemy w tomach 32-45 RGK z lat 1858-1861.

13 Ogólne informacje o czasopismach opracowano przede wszystkim na podstawie kolejnych roczników poszczególnych periodyków oraz jako uzupełnienie wykorzystano następujące opracowania: Bibliografia prasy polskiej 1832-1864, oprac. B. Korczak, Warszawa 1968; E. T o m a s z e w s k i, Prasa Królestwa Polskiego..., s. 116 i n.

14 Szerzej o nim zob. A. G ł o w a c k a, Kurowski Jan Nepomucen (1783-1866), [w:] PSB, t. 16, 1971 , s. 259-260.

15 W latach 1832-1833 ukazywał się „Pamiętnik Rolniczo-Technologiczny”, ale pismo szybko upadło po wydaniu 15 zeszytów. 
głównie informacje o postępie rolniczym, ulepszeniach, płodozmianie, uprawie roślin pastewnych (koniczyna, łubin), wykorzystywanych jako nawozy zielone, ale podejmowano na jego łamach także problemy związane z propagowaniem przemysłu spożywczego, głównie cukrownictwa i gorzelnictwa. Próbując zwalczyć trudności związane z brakiem odpowiedniej liczby prenumeratorów, od $1841 \mathrm{r}$. spółka wydawnicza przekształciła pismo w nowy periodyk pod nazwą „Ziemianin. Tygodnik Rolniczo-Technologiczny", ukazujący się do 1844 r. Jednak tematyka tego pisma to nadal gospodarstwo wiejskie i domowe, rolnictwo, hodowla zwierząt, technika rolna i przemysłowa, ogrodnictwo, leśnictwo itp. Z pismem związali się profesorowie Instytutu Agronomicznego w Marymoncie. Kilka lat później, w 1845 r., przywrócono pierwotną nazwę - „Tygodnik Rolniczo-Technologiczny”.

Kolejne czasopisma z kategorii społeczno-ekonomicznych, jak wspomniano wcześniej, zaczynały swoją karierę na rynku prasowym Królestwa Polskiego jako dodatki do gazet ogólnoinformacyjnych, rywalizujących ze sobą o kolejnych abonentów.

„Korespondent Handlowy, Przemysłowy i Rolniczy” wydawany był od lipca 1841 r. Początkowo stanowił dodatek do najstarszego wydawnictwa ogólnoinformacyjnego Królestwa Polskiego, „Gazety Warszawskiej” i ukazywał się wówczas dwa razy na tydzień. Nowa redakcja „Gazety Warszawskiej” z młodym Antonim Lesznowskim na czele ${ }^{16}$, mając w 1841 r. zaledwie 400 prenumeratorów, uruchomiła „Korespondenta” celem urozmaicenia swojej oferty, konkurując na rynku prasowo-wydawniczym Królestwa Polskiego. O postępie rolniczym na łamach pisma pisywali przede wszystkim Benedykt Aleksandrowicz i Jan Kanty Gregorowicz. Pismo poświęcone było produkcji roślinnej i zwierzęcej, wiadomościom handlowym, leśnictwu, ciekawostkom rolniczym i przemysłowym, a także zawierało informacje z kursów giełdy warszawskiej. Znaczną jego część zajmowały przedruki z innych periodyków i tłumaczenia. W 1855 r. zmieniał się dwukrotnie tytuł czasopisma, wpierw na „Korespondent Handlowy, Rolniczy i Przemysłowy” (od numeru 80.), a następnie na „Korespondent Rolniczy, Handlowy i Przemysłowy" (od numeru 86.).

Jeden z głównych konkurentów „Gazety Warszawskiej” w latach czterdziestych XIX w., „Gazeta Codzienna”, borykająca się z trudnościami finansowymi, również zdecydowała się na wydawanie dodatku o charakterze społeczno-ekonomicznym. W latach 1842-1845 jej redakcja publikowała cotygodniowy dodatek pod nazwą "Gazeta Handlowa i Przemysłowa”. Od 1845 do 1849 r. dodatek ukazywał się pod zmodyfikowaną nazwą „Gazeta Handlowa, Przemysłowa i Rolnicza”, natomiast od 1850 r. przekształcił się w samodzielny periodyk pod nazwą "Gazeta Rolnicza, Przemysłowa i Handlowa” - jako tygodnik ukazywał się do końca 1860 r. (od początku roku 1861 zmieniono tytuł na „Gazetę Rolniczą"). Pismo propagowało oczynszowanie chłopów, cukrownictwo, porady praktyczne, zamieszczało opisy rolnicze guberni i powiatów.

W latach 1851-1856, dwa razy w tygodniu, ukazywał się „Przegląd Rolniczy, Handlowy i Przemysłowy” jako dodatek do nowo założonego w 1851 r. ogólnoinformacyjnego „Dziennika Warszawskiego”. Wydawca pisma, Henryk Rzewuski,

${ }^{16}$ E. S z w a n k o w s k i, Lesznowski Antoni (1815-1859), [w:] PSB, t. 17, 1972, s. 163-165. 
znany ze swego serwilizmu i prorosyjskiego nastawienia ${ }^{17}$, zaczął wydawać nowoczesny periodyk, który początkowo pozyskał liczne, jak na warunki Królestwa Polskiego, grono prenumeratorów. Kiedy od 1 kwietnia 1856 r. „Dziennik Warszawski”, po opuszczeniu wcześniej Warszawy przez H. Rzewuskiego, zmienił nazwę na „Kronika Wiadomości Krajowych i Zagranicznych”, zmodyfikowano także tytuł dodatku na „Przegląd Rolniczy, Przemysłowy i Handlowy”. Ukazywał się do 1859 r., będąc organem „rolników [ziemian - J.K.] i zbliżonych grup społecznych”.

Analiza treści kolejnych tomów i numerów ogólnie scharakteryzowanych wcześniej czasopism społeczno-ekonomicznych Królestwa Polskiego z lat czterdziestych i pięćdziesiątych XIX w. pod kątem ich przydatności do badań dziejów szkolnictwa i oświaty przyniosła następujące konstatacje. Periodyki te z pewnością nie mogą być wykorzystywane jako źródło do badań nad oświatą ogólną. Prasa ograniczona skrupulatną cenzurą nie była w stanie zabrać głosu w kwestiach, które musiałyby zostać poddane niemal totalnej krytyce, gdyż to zakończyłoby się represjami dla redaktora naczelnego, a nawet mogło doprowadzić do zamknięcia pisma. Polityka oświatowa władz zaborczych była z pewnością diametralnie odmienna od oczekiwań nie tylko elity społeczeństwa polskiego. Z drugiej strony jakiekolwiek podjęcie kwestii związanych z funkcjonowaniem systemu oświaty i szkolnictwa w Królestwie Polskim bez słowa krytyki mogło narazić publicystów na ostracyzm ze strony i tak przecież nielicznych abonentów. A to doprowadziłoby do upadku pisma.

W takim razie nasuwa się pytanie, czy w ogóle czasopisma społeczno-ekonomiczne Królestwa Polskiego mogą być wykorzystywane jako źródło do badania dziejów szkolnictwa i oświaty. Na tak postawione pytanie można sformułować pozytywną odpowiedź. Czasopisma te przynoszą szereg cennych informacji poświęconych przede wszystkim szeroko pojętej pozaszkolnej oświacie rolniczej oraz szkolnictwu zawodowemu, w tym szczególnie typu rolniczego. Wynikało to z założeń programowych skrupulatnie realizowanych przez redakcje i spółki wydawnicze poddanych analizie czasopism, czyli omawianie i propagowanie wszelkich działań zmierzających do modernizacji gospodarki wiejskiej i polskiego rolnictwa. Dlatego też na łamach pism pojawiały się opisy wzorcowych gospodarstw folwarcznych, w których wprowadzano wszelkie nowinki agronomiczne i agrotechniczne, a ponadto ich właściciele czy rządcy byli praktycznymi zwolennikami uprzemysławiania majątków ziemskich ${ }^{18}$. Te niezmiernie szczegółowe opisy miały stanowić nieformalne podręczniki, poradniki zachęcające do porzucenia dawnego sposobu gospodarowania i zastosowania zalecanych innowacji. $\mathrm{Na}$ stronach analizowanych czasopism pojawiały się również opisy wzorowych

17 Szerzej zob.: A. Ś I i s z, Henryk Rzewuski. Życie i poglądy, Warszawa 1986, passim.

18 Od pierwszego tomu RGK regularnie pojawiały się dosyć szczegółowe opisy wzorcowych majątków ziemskich. W tomie 1. z 1842 r. A. Goltz zamieścił programowy artykuł pt. O potrzebie bliższego badania i opisywania krajowych gospodarstw oraz o korzyściach jakie z tego dla ogółu wyniknąć mogą, RGK 1842, t. 1, s. 110-125. Tytułem przykładu opisy wzorcowych majątków ziemskich, traktowane również jako propagowanie postępu rolniczego i oświaty pozaszkolnej, pojawiły się w następujących tomach RGK: 1842, t. 1; 1844, t. 4; 1845, t. 6; 1845, t. 7; 1852, t. 21; 1856, t. 29; 1858, t. 33; 1859, t. 36; 1860, t. 38; 1860, t. 40. Przedruki z RGK pojawiały się na łamach innych czasopism, m.in. „Gazety Handlowej, Przemysłowej i Rolniczej”, chociażby w numerach z 1849 r. 
gospodarstw chłopskich, a ich właściciele i dzierżawcy podawani byli jako przykłady skutecznego oddziaływania pozaszkolnej oświaty rolniczej ${ }^{19}$.

Czasopisma społeczno-ekonomiczne zamieszczały cały szereg informacji na temat szkolnictwa zawodowego, którego celem miało być przygotowanie odpowiednio wykształconych kadr dla potrzeb nowoczesnej gospodarki wiejskiej, w tym przemysłu rolno-spożywczego. Szczególnie wiele miejsca poświęcano najważniejszej instytucji oświatowej tego typu w skali ziem polskich w latach międzypowstaniowych, czyli Instytutowi Agronomicznemu w Marymoncie ${ }^{20}$. Działalność tej placówki została reaktywowana w 1836, a od 1840 r. zmieniono jej nazwę na Instytut Gospodarstwa Wiejskiego i Leśnictwa. Uzyskała wówczas charakter szkoły półwyższej, przyjmowano do niej kandydatów, którzy ukończyli przynajmniej 6 klas gimnazjum. Po kolejnej reorganizacji w 1857 r. Instytut Marymoncki uzyskał status szkoły wyższej. Mieli do niej wstęp wyłącznie absolwenci gimnazjów i wyższych szkół realnych ${ }^{21}$. Czasopisma społeczno-ekonomiczne podkreślały istotną rolę tej szkoły w systemie edukacyjnym Królestwa Polskiego. Szeroko rozpisywano się na temat kadry dydaktycznej placówki, ze znakomitymi profesorami Michałem Oczapowskim²2, Sewerynem Zdzitowieckim ${ }^{23}$ i Wojciechem Jastrzębowskim ${ }^{24}$ na czele. Na łamach prasy omawiano różnorodne doświadczenia przeprowadzane w salach laboratoryjnych oraz innowacje wprowadzane w folwarkach doświadczalnych szkoły. Ponadto najlepsi słuchacze Instytutu uzyskali możliwość zamieszczania na stronicach tych czasopism swoich sprawozdań z odbywanych praktyk rolniczych lub wędrówek po wzorowych majątkach ziemskich Królestwa Polskiego, mających miejsce w okresach wakacyjnych ${ }^{25}$. Warto podkreślić,

19 „Tygodnik Rolniczo-Technologiczny” 1837, R. III; RGK 1845, t. 6; 1849, t. 13; 1851, t. 18; 1851, t. 19; Gospodarstwa wiejskie w gub. lubelskiej, radomskiej, płockiej, augustowskiej i warszawskiej, „Gazeta Handlowa, Przemysłowa i Rolnicza” 1849.

20 J. Ł., Wiadomość o praktycznem kształceniu uczniów Instytutu Gospodarstwa Wiejskiego w Marymoncie, RGK 1844, t. 4. Ponadto wzmianki o Instytucie pojawiały się przy okazji różnych artykułów o szkolnictwie rolniczym i gospodarstwie rolnym oraz przy relacjach i opisach majątków sporządzanych przez praktykantów z Marymontu.

21 Ustawa dla Instytutu Gospodarstwa Wiejskiego i Leśnictwa, „Sylwan” 1841, t. 17, cz. 1, s. $350-375$.

22 Michał Oczapowski (1788-1854) - profesor Uniwersytetu Wileńskiego w latach 1822-1832. Był dyrektorem Instytutu Gospodarstwa Wiejskiego i Leśnictwa w Marymoncie w latach 1836-1853. Znakomity polski agronom, autor wielu prac z zakresu gospodarstwa wiejskiego, agronomii i chemii. Uznawany za prekursora nowoczesnego rolnictwa na ziemiach polskich.

${ }^{23}$ Seweryn Zdzitowiecki (1802-1879) - chemik i metalurg. Studiował w Uniwersytecie Warszawskim, na Sorbonie i w Getyndze. Doskonalił swoją wiedzę praktyczną w Niemczech i we Francji. W latach 1853-1860 był dyrektorem Instytutu Gospodarstwa Wiejskiego i Leśnictwa w Marymoncie. Autor wielu artykułów propagujących wiedzę rolniczą, głównie nawożenie gleb. Był też autorem podręcznika Wykład początkowy chemii.

${ }^{24}$ Wojciech Jastrzębowski (1799-1882) - profesor botaniki, fizyki, zoologii i ogrodnictwa w Instytucie Gospodarstwa Wiejskiego i Leśnictwa w Marymoncie. Jeden z głównych twórców ergonomii. Autor różnych prac naukowych i Traktatu o Wiecznym Przymierzu Między Narodami Ucywilizowanymi - Konstytucja dla Europy (1831).

${ }^{25} \mathrm{~L}$. J a strzę bow ski, Wspomnienie z podróży przez uczniów Instytutu Gospodarstwa Wiejskiego i Leśnictwa w Marymoncie, pod przewodnictwem profesora Wojciecha Jastrzębowskiego, po kraju odbytej, w miesiącach lipcu i sierpniu 1853 roku, RGK 1854, t. 25, s. 239 i n. Ponadto relacje praktykantów, np.: RGK 1849, t. 14, 1849, t. 15; 1850, t. 16; 1852, t. 21; 1856, t. 29. 
że pomiędzy 1841 a 1861 r. przez Instytut Agronomiczny w Marymoncie przeszło ponad 1500 wychowanków ${ }^{26}$.

Czasopisma społeczno-ekonomiczne nie ograniczały się wyłącznie do informowania o Instytucie Marymonckim. Redakcje, popularyzując szkolnictwo rolnicze jako najbardziej odpowiednie w tym okresie dla młodych Polaków, wywodzących się z ziemiaństwa, sfer urzędniczych, inteligencji i drobnej szlachty cząstkowej, zamieszczały opisy innych tego typu szkół, funkcjonujących bądź zakładanych na terenie Galicji oraz w krajach, w których oświata rolnicza stała na wysokim poziomie. Znajdujemy więc relacje z peregrynacji do uczelni i zawodowych szkół rolniczych, istniejących w krajach niemieckich, we Francji i w Anglii (m.in. w Antwerpii, Regenwalde, Paryżu, Versailles), a także z uroczystości otwarcia wyższej szkoły rolniczej w galicyjskich Dublanach ${ }^{27}$.

$\mathrm{Na}$ łamach analizowanych czasopism pojawiały się również teksty podejmujące kwestie oświaty ludowej i szkolnictwa wiejskiego. Należy wyraźnie zaakcentować, że nie były to jednak w zdecydowanej większości samodzielne artykuły poświęcone tym zagadnieniom, lecz treści te podejmowano niejako przy okazji pisania o szeroko pojętej kwestii agrarnej ${ }^{28}$. Szczególnie po rabacji galicyjskiej i wydarzeniach Wiosny Ludów rozwiązanie tzw. kwestii włościańskiej stało się wyjątkowo palącym problemem dla środowiska ziemiańskiego i związanej z nim części inteligencji. W kręgach postępowej elity propagującej modernizację Królestwa Polskiego toczył się dyskurs dotyczący skali i czasu uregulowania kwestii włościańskiej. Jednak wszyscy jego uczestnicy byli zgodni, że skoro należy przeprowadzić reformę stosunków wiejskich, to trzeba również wziąć pod uwagę oświatą dla ludu i zakres edukacji dzieci chłopskich ${ }^{29}$. Pomysły w tej sprawie, pojawiające się na łamach czasopism społeczno-ekonomicznych, były w zasadzie formułowane w tym samym duchu (tonie). Postaram się krótko zarysować sedno problemu.

Publicyści byli zgodni, że zakładanie wiejskich szkółek elementarnych i podnoszenie poziomu umysłowego młodego pokolenia chłopów było niezbędne w procesie modernizacji stosunków społecznych i gospodarczych w Królestwie Polskim. Sprawa szkolnictwa wiejskiego urastała do rangi bez mała pierwszoplanowego problemu społecznego dla liderów „partii ziemiańskiej”. Zdawano sobie sprawę, że planowana reforma agrarna ostatecznie zniesie zależność wsi od dworu i nastąpi emancypacja ludności chłopskiej, a stosunki pomiędzy obu środowiskami mogą rozwijać się w niepożądanym kierunku. Podkreślano więc, iż tylko podjęcie energicznej, odpowiednio ukierunkowanej akcji oświatowo-wychowaw-

${ }^{26}$ W. G r a b s k i, Historia ..., t. 1, s. 203.

27 S. Zdz., Instytut agronomiczny w Versailles, RGK 1853, t. 22; S. Zdz., Szkoła centralna sztuk i rękodzieł w Paryżu, RGK 1853, t. 22; A. H., Opis akademii rolniczej w Regenwalde, z niektórymi nad nią uwagami, RGK 1853, t. 23; 1854, t. 24; A. hr Z., Wyższa szkoła handlowa w Antwerpii, RGK 1855, t. 27; Uroczyste otwarcie szkoły rolniczej w Dublanach, RGK 1857, t. 30; C. H., Kilka słów o szkołach gospodarstwa wiejskiego, RGK 1862, t. 46.

${ }_{28}$ Por. J. K i t a, Tomasz Potocki..., rozdz. V.

29 J. K i t a, Ziemiańskie pomysły szkolnictwa wiejskiego w Królestwie Polskim w połowie XIX wieku, „Dobrzyckie Studia Ziemiańskie” 2010, nr 1, red. M. Jaeger i in., s. 68-84. 
czej na wsi może wywołać poprawę istniejącego stanu rzeczy. Niektórzy publicyści ziemiańscy (A. Zamoyski, L. Górski, T. Potocki) traktowali rozwój oświaty na wsi w kategoriach długu, ciążącego na tej warstwie - potomkach szlachty - wobec chłopów polskich ${ }^{30}$.

Należy natychmiast zastrzec, że nie chodziło im wcale o dopuszczenie dzieci chłopskich do wykształcenia wyższego czy nawet średniego, które traktowano jako zbyteczne dla nich i ich potrzeb życiowych. Kierowano się zasadą, że warstwy najniższe powinny otrzymać jedynie tyle wiadomości, ile przynależy ich stanowi. Jednym słowem, chłopów należało jedynie nauczyć pisania i czytania oraz zasad arytmetyki. Jednocześnie najistotniejszym przedmiotem w szkółkach gromadzkich winna być nauka religii i moralności, umożliwiająca wpajanie dzieciom chłopskim od najmłodszych lat szacunku dla władzy świeckiej i duchownej, czyli wójta-dziedzica i księdza, a ponadto kształtująca obowiązkowość, pracowitość i poszanowanie cudzej własności. Szkoła taka, zdaniem publicystów, winna spopularyzować wśród młodego pokolenia chłopów ideę solidaryzmu społecznego, zasadę współpracy i zaufanie do elit, które strzegły najcenniejsze polskie wartości i tradycję narodową. Wykazywano, że kształcenie na poziomie elementarnym powinno być obowiązkowe i bezpłatne, aby mogło stać się powszechne i dostępne również dla najuboższych mieszkańców wsi. Istotnym elementem postulowanego systemu oświaty i wychowania ludu wiejskiego powinny być również ochronki, zakładane z inicjatywy dworu i plebanii, którym również poświęcono kilka artykułów.

$\mathrm{Na}$ łamach poddanych analizie czasopism pojawiały się również koncepcje przyszłej struktury szkolnictwa wiejskiego. Na najniższym szczeblu miały znajdować się wspomniane wcześniej elementarne szkółki gromadzkie, dostępne dla wszystkich dzieci chłopskich. Dla najzdolniejszych przewidywano dalszą drogę edukacyjną w postaci szkół rolniczo-włościańskich, które kształciłyby wzorowych gospodarzy, propagujących w swoim środowisku nowoczesną wiedzę rolniczą oraz podnosiliby ogólny poziom kultury na wsi. Trzeci rodzaj winny stanowić szkoły rzemieślniczno-włościańskie, kształcące fachowców dla wiejskiego rzemiosła. Dostęp do wyższych szczebli edukacji szkolnej dla młodzieży wiejskiej pomijano milczeniem ${ }^{31}$.

Przyjrzyjmy się jeszcze, kto pisał na łamach pism społeczno-ekonomicznych Królestwa Polskiego w tym okresie? Na różne tematy, w tym te poświęcone problematyce oświaty i szkolnictwa, wypowiadali się wyłącznie mężczyźni. Nie mieli oni, co prawda, wykształcenia pedagogicznego, ale byli to najczęściej wybitni teoretycy i praktycy w dziedzinie agronomii, agrotechniki i gospodarstwa wiejskiego, którzy jednocześnie, dzięki zagranicznym peregrynacjom, mieli możliwość poznania najnowszych osiągnięć w interesujących ich dziedzinach. Ponadto

${ }^{30}$ A.Z., O szkółkach rolniczych wiejskich, RGK 1849, t. 14, s. 271-278; [T. Potocki], Poranki karlsbadzkie, czyli rozbiór zarzutów, uzupełnień i uwag nad pismem „O urządzeniu stosunków rolniczych w Polsce przez Adama Krzyżtopora", Poznań 1858.

${ }^{31}$ A. Z a m o y s k i, O szkółkach rolniczych..., s. 271-278; A. A. K., Myśli o rozpowszechnianiu piśmiennictwa między ludem wiejskim, RGK 1862, t. 46, s. 41-65; A. G o I t z, O położeniu obecnym właścicieli ziemskich, RGK 1862, t. 46, s. 258; [T. Potocki], Poranki karlsbadzkie..., s. 249 i n. 
niektórzy z nich byli właścicielami nowoczesnych majątków ziemskich, doskonale znali stan, sytuację i stosunki społeczno-gospodarcze, panujące w Królestwie Polskim, a szczególnie w dworach i chatach wiejskich. Wiedzą tą starali się podzielić z czytelnikami czasopism społeczno-ekonomicznych, proponując najbardziej wartościowe, według nich, rozwiązania, chociaż, jak już wcześniej wspomniano, czynili to $z$ reguły patrząc poprzez pryzmat interesów własnych i swojej warstwy społecznej.

Reasumując, chciałbym podkreślić, że atmosfera przygnębienia i marazmu w Królestwie Polskim w latach popowstaniowych, mikołajowski system władzy i paskiewiczowski styl zarządzania, dosyć nieliczne i słabe elity intelektualne oraz poważnie ograniczone kontakty zagraniczne nie sprzyjały, do momentu klęski Rosji w wojnie krymskiej, nawet zdecydowanie ograniczonym inicjatywom społecznym. Świadectwem tego stanu rzeczy były nieliczne artykuły zamieszczane na łamach ówczesnej prasy, poświęcone całościowemu ujęciu systemu oświaty i szkolnictwa. Dopiero przełom lat pięćdziesiątych i sześćdziesiątych XIX stulecia przyniósł, na fali wiosny posewastopolskiej i nastrojów patriotycznych, lepszy klimat, pozwalający podjąć reformy systemu oświaty i sprzyjający pojawieniu się nowych koncepcji postulujących reorganizację szkolnictwa Królestwa Polskiego. Nastąpiło jednocześnie złagodzenie cenzury, co umożliwiało ożywienie życia intelektualnego. Odbiciem tego zwrotu stało się pojawienie na łamach ówczesnej prasy różnego typu poważniejszych i drobniejszych artykułów oraz toczące się polemiki nad kierunkiem reform. W tym dyskursie prym wiodły inne pisma, przede wszystkim ogólnoinformacyjne: „Gazeta Polska”, „Dziennik Powszechny” i „Gazeta Warszawska"32. Reformę systemu szkolnictwa, przy aprobacie cara Aleksandra II, przeprowadził w 1862 r. margrabia Aleksander Wielopolski ${ }^{33}$. Niepodważalna pozycja margrabiego w systemie władzy uniemożliwiała jakiekolwiek głosy krytyczne wobec przeprowadzonej reformy na stronach oficjalnej prasy Królestwa Polskiego. Krytycy i polemiści mogli więc wypowiadać się w tej sprawie jedynie na łamach prasy zakordonowej i emigracyjnej bądź tajnej.

32 Zob. R. W r o c z y ń s k i, Pedagogika, [w:] Historia nauki polskiej, red. B. Suchodolski, t. 3: 1795-1862, red. J. Michalski, Wrocław 1977, s. 778-784.

${ }^{33}$ K. P o z n a ń s k i, Reforma szkolna w Królestwie Polskim w 1862 r., Wrocław 1968, passim. 